\title{
First report on the contribution of small-sized species to the copepod community structure of the southern Patagonian shelf (Argentina, $47-55^{\circ} \mathrm{S}$ )
}

\author{
Julieta Carolina Antacli 1,2,3, Daniel Raúl Hernández ${ }^{2}$, Marina Elena Sabatini 1,2,3 \\ ${ }^{1}$ Consejo Nacional de Investigaciones Científicas y Técnicas (CONICET). Av. Rivadavia 1917, C1033AAJ, Buenos Aires, \\ Argentina. E-mail address: antacli@inidep.edu.ar \\ ${ }^{2}$ Instituto Nacional de Investigación y Desarrollo Pesquero (INIDEP). Paseo Victoria Ocampo 1, B7602HSA, \\ Mar del Plata, Argentina. \\ ${ }^{3}$ Instituto de Investigaciones Marinas y Costeras (IIMYC), CONICET-Universidad Nacional de Mar del Plata, Argentina.
}

\begin{abstract}
Summary: The copepod community structure, with special emphasis on small-sized species, was studied over the southern Patagonian shelf in late summer 2004, applying the first plankton sampling in the region with a fine-mesh $(66 \mu \mathrm{m})$ net. The key role of the copepods Drepanopus forcipatus and Calanus australis was confirmed, but also the high abundance and frequency of occurrence of the microcopepods Oithona helgolandica and Microsetella norvegica and of the medium-sized copepod Ctenocalanus vanus were revealed. Copepod community structure was nearly homogenous over the entire study area. Drepanopus forcipatus, $O$. helgolandica and $M$. norvegica were identified as the typical species of the region, although secondarily $C$. australis and Oithona atlantica also contributed significantly to community similarity across the area. The study of interspecific relationships of dominant copepods indicated that D. forcipatus and C. australis were associated positively with $O$. helgolandica, while $C$. vanus, and $M$. norvegica constituted a separate assemblage with Clausocalanus brevipes and $O$. atlantica. The importance of fine-mesh-size nets for collecting the smaller size fractions of mesozooplankton and for accurately portraying the mesozooplankton assemblage structure in the area is stressed by this study.
\end{abstract}

Keywords: mesozooplankton; microcopepods; southern Patagonian shelf; size spectra; Oithona helgolandica; Micosetella norvegica; Drepanopus forcipatus.

Primer informe sobre la contribución de microcopépodos a la estructura de la comunidad mesozooplanctónica de la plataforma patagónica austral (Argentina, 47-55 $\mathrm{S}$ )

Resumen: La estructura de la comunidad de copépodos, con especial énfasis en las especies de pequeño tamaño, se estudió en la plataforma patagónica austral durante el verano tardío de 2004, a partir del primer muestreo de plancton en la región con una red de malla fina $(66 \mu \mathrm{m})$. Se confirmó el rol clave de las especies Drepanopus forcipatus y Calanus australis, pero al mismo tiempo se evidenció la gran abundancia y frecuencia de ocurrencia de los microcopépodos Oithona helgolandica y Microsetella norvegica y del copépodo de tamaño medio Ctenocalanus vanus. La estructura de la comunidad de copépodos fue aproximadamente homogénea en toda el área de estudio. Drepanopus forcipatus, O. helgolandica y M. norvegica resultaron las especies típicas de la región y, aunque secundariamente, C. australis y Oithona atlantica también contribuyeron significativamente a la similitud en el área. El estudio de las interrelaciones entre las especies dominantes indicó que $D$. forcipatus y $C$. australis estuvieron positivamente asociados con $O$. helgolandica, mientras que $C$. vanus y $M$. norvegica conformaron otra asociación con Clausocalanus brevipes y $O$. atlantica. A partir de este estudio se enfatiza la importancia de las redes de malla fina para colectar las fracciones de tamaño más pequeñas del mesozooplancton y para describir correctamente la estructura de la comunidad mesozooplanctónica en el área.

Palabras clave: mesozooplancton; microcopépodos; plataforma patagónica austral; rango de tamaños; Oithona helgolandica; Micosetella norvegica; Drepanopus forcipatus.

Citation/Como citar este artículo: Antacli J.C., Hernández D.R., Sabatini M.E. 2014. First report on the contribution of small-sized species to the copepod community structure of the southern Patagonian shelf (Argentina, $47-55^{\circ}$ S). Sci. Mar. 78(1): 17-26. doi: http://dx.doi.org/10.3989/scimar.03906.31C

Editor: A. Ianora.

Received: June 13, 2013. Accepted: October 29, 2013. Published: February 24, 2014.

Copyright: () 2014 CSIC. This is an open-access article distributed under the Creative Commons Attribution-Non Commercial Lisence (by-nc) Spain 3.0. 


\section{INTRODUCTION}

Quantitative assessment of planktonic organisms is a key issue in determining food web structure and material cycling in pelagic ecosystems. In particular, reliable data on the mesozooplankton $(0.2-20 \mathrm{~mm})$, an important size class of the zooplankton community that links primary producers with higher trophic levels, are essential in order to accurately interpret the structure of marine pelagic ecosystems. The widespread use of coarse plankton nets with standard mesh sizes of 200$330 \mu \mathrm{m}$ to collect mesozooplankton has led researchers to focus primarily on large copepod species, and to substantially underestimate the abundance of smaller organisms. However, as a result of the increasing use of fine plankton nets, microcopepods (i.e. species with a total body length between 0.2 and $1.0 \mathrm{~mm}$ in the adult and early copepodite stages) are currently recognized as essential contributors to the mesozooplankton community (e.g. Hopcroft et al. 1998, Di Mauro et al. 2009) and to the secondary production of marine ecosystems (e.g. Turner 2004, Gallienne and Robins 2001, Zervoudaki et al. 2007, Narcy 2010).

Mesozooplankton communities of the southern Patagonian shelf have been well studied over the last 40 years. However, most of the information on the taxonomic composition (Ramírez 1970a, 1971, 1981), biomass patterns (Sabatini and Álvarez Colombo 2001, Sabatini et al. 2004, Sabatini 2008a), population traits and life strategies (Sabatini 2008b) of the zooplankton was obtained from samples collected with nets with a mesh size of $200 \mu \mathrm{m}$ (or larger). Therefore, the structure and function of the mesozooplankton community have been analysed in the region primarily for the larger, most abundant and most frequently occurring species captured by those standard nets. The smallest taxa, which are commonly undersampled and missed by coarse mesh sizes (e.g. Vanucci 1968, Evans and Sell 1985, Paffenhöfer 1998, Hwang et al. 2007, Pitois et al. 2009, Di Mauro et al. 2009) have been largely overlooked. Therefore, despite its importance, the overall structure of the zooplankton community of the Patagonian shelf has not been studied in detail, and species diversity patterns are poorly described.

As a result of sampling with coarse nets, two copepod species, the medium-sized clausocalanid Drepanopus forcipatus and the large calanid Calanus australis (mean prosome lengths are 983 and $2544 \mu \mathrm{m}$, respectively, Sabatini 2008b) are currently recognized as dominant components of the mesozooplankton biomass in the southern Patagonian shelf and are considered key species in the local planktonic food web. More recently, a study comparing the catching efficiency of plankton nets of 66 and $150 \mu \mathrm{m}$ mesh has revealed that smaller species and early developmental stages of copepods have been significantly underestimated, and community and population structures have been severely biased by the coarse net (Antacli et al. 2010). Specifically, abundances of the first copepodite stage (C1) of D. forcipatus, all copepodite stages of the small-sized cycolopoid Oithona helgolandica including their detached egg-sacs, and pooled nauplii of all species are undersampled by the coarse net. Although not statistically treated, Antacli et al. (2010) also showed the underestimation of the small harpacticoid Microsetella norvegica.

Especially in oligotrophic waters where the microbial trophic food web prevails, microcopepods are considered important connectors between the classical and microbial food webs (Turner 2004). The southern Patagonian shelf (SW Atlantic, $47-55^{\circ} \mathrm{S}$ ) is a cold-temperate ecosystem characterized by seasonal variation in biological production, following marked changes in abiotic conditions. During late summer and early autumn, primary production is low and the phytoplankton and protozoan zooplankton communities are dominated by ultraplanktonic cells (Alder and Franzosi 2003, 2005, Almandoz et al. 2007, Antacli 2011, Silva unpublished data), while abundances of larger nanoplankton and microplankton are low (Olguín et al. 2005, Santoferrara and Alder 2009a,b, Cefarelli et al. 2010, Antacli 2011, Akselman unpublished data). This size structure indicates the dominance of a microbial trophic web sustained by pico- and nanoeukariotes and bacterioplankton in the inner area of the Patagonian shelf during late summer (Antacli 2011, Antacli et al. submitted). Taking those previous observations into account, the smaller and less studied copepod taxa may have important roles in the local planktonic food web. Their relative contributions to the copepod community and to trophic transfers, along with those of $D$. forcipatus and $C$. australis, deserve revision on the basis of sampling with fine-mesh nets.

The overall objective of this study was to examine the structure of the copepod community, with particular reference to small-sized species, by sampling plankton for the first time over the southern Patagonian shelf in late summer with a fine-mesh $(66 \mu \mathrm{m})$ net. We specifically tested the hypothesis that microcopepods are major contributors to the copepod community in the region during summer. We report here (i) the specific composition, abundance and spatial distribution of the copepod community, (ii) the spatial distributions of distinctive copepod assemblages and (iii) the interspecific relationships of dominant copepods.

\section{MATERIALS AND METHODS}

\section{Sampling}

The study area extended over the continental shelf off southern Patagonia ( 47-55 $\left.{ }^{\circ} \mathrm{S} / 61-69^{\circ} \mathrm{W}\right)$. Mesozooplankton was collected in late summer (March/April 2004) on a cruise aboard RV Dr. E. L. Holmberg at 32 stations along four latitudinal transects (Fig. 1). A small, vertically retrieved Bongo sampler (mouth opening $20 \mathrm{~cm}$, nets of 66 and $150 \mu \mathrm{m}$ mesh size) was used to collect samples from just above the bottom or from a maximum depth of about $100 \mathrm{~m}$. A weight of $18 \mathrm{~kg}$ was attached to the center of the frame to overcome the drag of the sampler. Wire angles were thus maintained close to vertical and the nets were retrieved at a wire speed of $10 \mathrm{~m}$ per minute. Filtered volumes were estimated with digital flowmeters (Hydro-Bios) positioned 


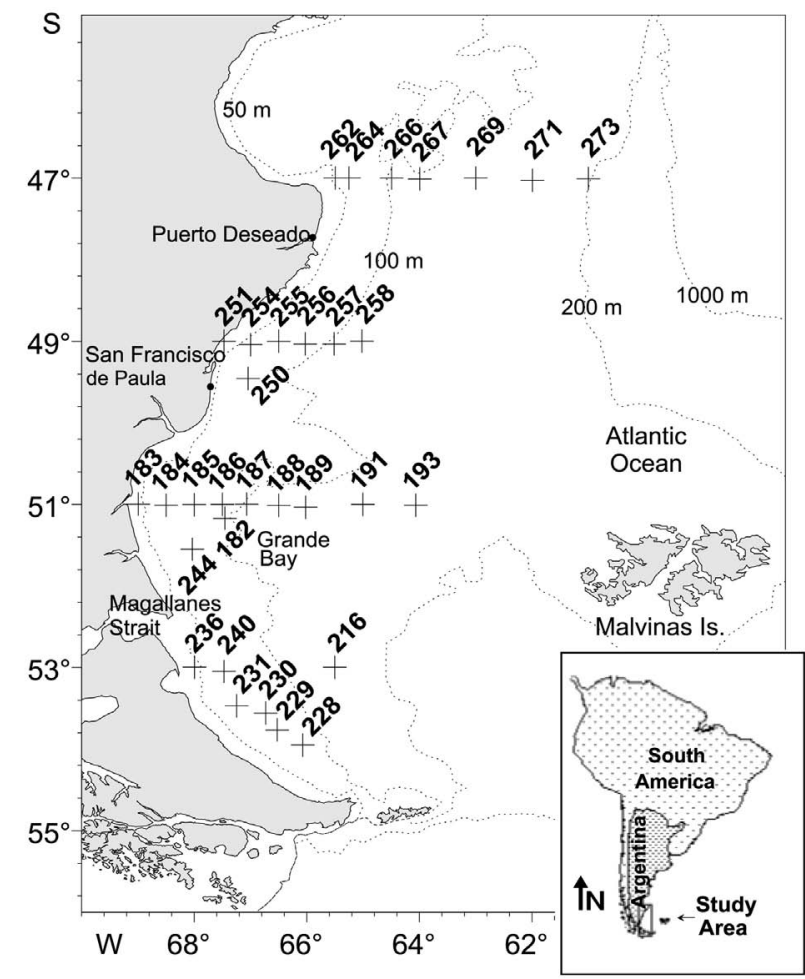

Fig. 1. - Mesozooplankton sampling stations (crosses) over the southern Patagonian shelf during the cruise EH-03/04 (INIDEP) carried out in late summer March/April, 2004 onboard RV Dr. E.L Holmberg.

in the mouths of the nets (on average $4.6 \pm 2.6 \mathrm{~m}^{3}$ and $5.1 \pm 2.7 \mathrm{~m}^{3}$ for the 66 and $150 \mu \mathrm{m}$ nets, respectively). Samples were preserved in $4 \%$ buffered-formaldehyde for later analysis in the laboratory. The time of zooplankton collection depended on the arrival at stations after the general course of the cruise (17 stations were sampled during daylight hours and 15 at night). However, this contingency should not be a drawback because zooplankton samples were representative of the whole water column. In contrast, we are aware that larger and faster-swimming zooplankton (mainly euphausiids, amphipods and chaetognats which did occur in the samples) were most likely undersampled by the small Bongo due to the low retrieving speed and smallsized mouth of the sampler. Therefore, those groups were excluded from analysis.

\section{Copepod species and abundance}

Identification of copepods was accomplished after Grandori (1912), Ramírez (1970b, 1971, 1981), Heron and Bowman (1971), Björnberg (1981), Bradford et al. (1988), Sabatini (1990), Hulsemann (1991), BradfordGrieve (1999) and Ramírez and Sabatini (2000).

On the basis of previous results regarding mesh selection effects in the study area (Antacli et al. 2010), quantitative data were estimated from the samples collected with the fine $66-\mu \mathrm{m}$ net. Individuals were counted under a stereomicroscope (Leica M8). Separate subsamples were used for quantifying each species/taxon because of their different abundances in the samples. That is, samples were split into a series of suc- cessive aliquots accordingly to the relative abundances of taxa. The aim was to count at least 200 individuals of the most abundant stage in each sample (Postel et al. 2000). On the other hand, the entire sample was analysed when copepods were few. Nauplii were not identified to species or stage but pooled for counting.

Counting results were organized into three groups according to organism size: (i) adult (C6) and copepodite stages (C1-C5) of large copepods (e.g. Calanidae, Eucalanidae, Rhincalanidae), (ii) C1-C6 of small and medium-sized copepods (e.g. Clausocalanidae, Harpacticoida, Cyclopoida), and (iii) other small-sized items (e.g. naupliar stages, egg-sacs of Oithona spp. and fecal pellets). The relative abundance, RA\%

$$
R A_{i}=100\left(\sum_{j=1}^{S} x_{i j} / \sum_{i=1}^{I} \sum_{j=1}^{S} x_{i j}\right),
$$

i.e. the average contribution of each taxon $i$ to the total abundance, $I$ being the total number of taxa and $S$ the total number of samples] and the frequency of occurrence, $F O \%\left[F O_{i}=100\left(n_{j i} / S\right)\right.$, i.e. the number of samples $j$ in which a given taxon $i$ occurs in relation to the total number of samples $(S)]$ were then calculated.

\section{Statistical analyses}

\section{Copepod community structure}

Multivariate statistics were used to examine the copepod community structure in general, and specifically to identify the typical species within the copepod community and to analyse the spatial distribution of copepod assemblages. Analyses were performed with the PRIMER software package (Clarke and Warwick 1994) version 5.2.9 (Primer-E). We used an initial matrix composed of 23 copepod species/taxa and 32 samples. The analyses included all the species, even the rare taxa (i.e. those with low relative abundance and low frequency of occurrence) (Clarke and Warwick 1994). The abundance data, $x_{i}$, for each species, $i$, were transformed to $x^{\prime}{ }_{i}=\ln \left(x_{i}+1\right)$ to reduce the influence of the most abundant species.

A similarity matrix was produced from the natural logarithms of the abundance data by calculating the Bray-Curtis similarity measure. Then, a one-way analysis of similarity (ANOSIM, Clarke and Warwick 1994) was used to test whether the copepod community structure showed significant differences among four latitudinal sections $\left(47,49,51\right.$, and $\left.53^{\circ} \mathrm{S}\right)$ or between two bathymetric areas: inner shelf and mid-shelf. Those regions were defined a priori because we assumed the existence of variations in the copepod distribution patterns as functions of latitude and longitude. Data from the bathymetric areas were grouped according to station depth, for comparison of inner shelf ( $\leq 50-100 \mathrm{~m})$ and mid-shelf $(\geq 100-200$ $\mathrm{m})$ communities. ANOSIM is analogous to one-way ANOVA and based on the statistic $R$, which quantifies the distinctions among the groups. $R$ values near to 1 indicate large differences among groups; $R$ values near to 0 indicate small differences; negative $R$ values 
indicate that differences within groups are larger than between groups. $R$ values $>0.75$ represent well separated groups, $R$ values $>0.5$ indicate overlapping but clearly different groups and $R$ values $<0.25$ suggest barely separable groups (Clarke and Warwick 1994, Clarke and Gorley 2001).

A similarity percentage routine (SIMPER, Clarke and Warwick 1994) was applied to the ln-transformed abundance values $\left(x_{i}^{\prime}\right)$ in order to identify the copepod taxa contributing the most to average similarity across the entire study area. SIMPER examines how much each species contributes to the average similarity, $\bar{S}_{i}$, within a group of samples (the more abundant the species the more it contributes). It is considered that a species typifies a group if it is found at a consistent abundance throughout. In that case, the standard deviation of its contribution to similarity, $s d\left(S_{i}\right)$, will be low, and the ratio $\bar{S}_{i} / s d\left(S_{i}\right)$ will be high (Clarke and Warwick 1994). In this study the species contributing to similarity with $\bar{S}_{i}$ values $\geq 10 \%$ were considered typical species (Bulleri et al. 2005).

\section{Copepod assemblages}

To portray the spatial association between dominant copepod species, a principal component analysis (PCA) based on the correlation matrix was performed (STATISTICA v.7). This is a simple, graphical way to examine the relationships among species. In such analyses the variables (species) are represented on the ordination space of the first two components by their correlation values, all of which will be included within the correlation circle. Those falling close to one other within the correlation circle are positively correlated, while those placed in opposite quadrants are negatively correlated (Borouche and Saporta 1983). An index of importance, I, was calculated for each species/taxon, $i$, as the average of the relative abundance and the frequency of occurrence, in order to identify the dominant species (after Morales et al. 2010). Then, only the species with $I$ values $\geq 20 \%$ were considered important and included in the PCA. This procedure excluded the rare species from the analysis and, thereby, reduced the noise level. Abundance values were standardized and ln-transformed before the PCA.

\section{RESULTS}

\section{Abundance and distribution of copepod species}

A total of 23 copepod taxa were identified over the study area (Table 1). Drepanopus forcipatus was the most numerous species at all stations, accounting for $79 \%$ of total copepod numerical abundance. Oithona helgolandica was next with $15 \%$. Ctenocalanus vanus, Calanus australis and Microsetella norvegica contributed much less to total numbers, accounting for 1 to $2 \%$ each. The least abundant copepod taxa accounted for $<0.1 \%$ and are all listed in Table 1 (see also Fig. 2A).

Drepanopus forcipatus and $O$. helgolandica occurred at all stations $(F O=100 \%)$. Microsetella norvegica, C. australis, C. vanus, Oithona atlantica and Clausocalanus brevipes were frequent taxa, being present at 59 to $88 \%$ of the sampled sites. Less frequent copepods were Acartia tonsa, Neocalanus tonsus, Rhincalanus nasutus, Calanus simillimus, Calanoides cf. patagoniensis, Metridia lucens and Siphonostomatoida sp. $(F O=15-25 \%)$, while all other taxa occurred occasionally $(F O<15 \%)$ (Table 1, Fig. 2B).

Table 1. - List of copepod species/taxa collected with a 66- $\mu \mathrm{m}$ mesh net (small Bongo sampler) over the southern Patagonian shelf in March/ April 2004. Taxonomic classification after Boxshall and Halsey (2004). $R A$, relative abundance; $F O$, frequency of occurrence; $I$, index of importance (average between $R A$ and $F O$ ). Important or dominant species are in bold $(I \geq 20 \%)$.

\begin{tabular}{|c|c|c|c|c|c|}
\hline $\begin{array}{l}\text { ORDER } \\
\text { Family }\end{array}$ & Species/taxa & $\begin{array}{l}\text { Abundance range } \\
\quad \text { (ind } \mathrm{m}^{-3} \text { ) }\end{array}$ & $\begin{array}{l}R A \\
(\%)\end{array}$ & $\begin{array}{l}F O \\
(\%) \\
\end{array}$ & $I$ \\
\hline \multicolumn{6}{|l|}{ CALANOIDA } \\
\hline Augaptilidae & Euaugaptilus sp. & $0-3$ & 0.001 & 3 & 1.50 \\
\hline Metridinidae & Metridia lucens & $0-14$ & 0.01 & 16 & 8.01 \\
\hline \multirow[t]{3}{*}{ Clausocalanidae } & Drepanopus forcipatus & 8-79732 & 79.4 & 100 & 89.7 \\
\hline & Clausocalanus brevipes & $0-431$ & 0.26 & 59 & 29.63 \\
\hline & Ctenocalanus vanus & $0-3417$ & 1.57 & 69 & 35.29 \\
\hline \multirow[t]{4}{*}{ Calanidae } & Calanus australis & $0-1898$ & 1.45 & 84 & 42.73 \\
\hline & Calanus simillimus & $0-115$ & 0.03 & 16 & 8.02 \\
\hline & Neocalanus tonsus & $0-232$ & 0.08 & 19 & 9.54 \\
\hline & Calanoides cf. patagoniensis & $0-2$ & 0.001 & 16 & 8.00 \\
\hline \multirow[t]{2}{*}{ Paracalanidae } & Paracalanus parvus & $0-464$ & 0.12 & 13 & 6.56 \\
\hline & Calocalanus sp. & $0-8$ & 0.003 & 9 & 4.50 \\
\hline Acartiidae & Acartia tonsa & $0-1540$ & 0.59 & 25 & 12.80 \\
\hline Centropagidae & Centropages sp. & $0-9$ & 0.002 & 6 & 3.00 \\
\hline Eucalanidae & Eucalanus sp. & $0-0.2$ & 0.0001 & 3 & 1.50 \\
\hline Rhincalanidae & Rhincalanus nasutus & $0-1$ & 0.001 & 16 & 8.00 \\
\hline \multicolumn{6}{|l|}{ CYCLOPOIDA } \\
\hline \multirow[t]{4}{*}{ Oithonidae } & Oithona helgolandica & $9-11603$ & 15.1 & 100 & $\mathbf{5 7 . 5 5}$ \\
\hline & Oithona nana & $0-132$ & 0.1 & 13 & 6.55 \\
\hline & Oithona atlantica & $0-197$ & 0.14 & 69 & 34.57 \\
\hline & Oithona cf. plumifera & $0-3$ & 0.001 & 3 & 1.50 \\
\hline \multicolumn{6}{|l|}{ HARPACTICOIDA } \\
\hline \multirow[t]{2}{*}{ Ectinosomidae } & Microsetella norvegica & $0-917$ & 1.11 & 88 & 44.56 \\
\hline & Euterpina acutifrons & $0-5$ & 0.001 & 3 & 1.50 \\
\hline Clytemnestridae & Clytemnestra rostrata & $0-0.3$ & 0.0001 & 3 & 1.50 \\
\hline SIPHONOSTOMATOIDA & Siphonostomatoida sp. & $0-6$ & 0.002 & 16 & 8.00 \\
\hline
\end{tabular}


A

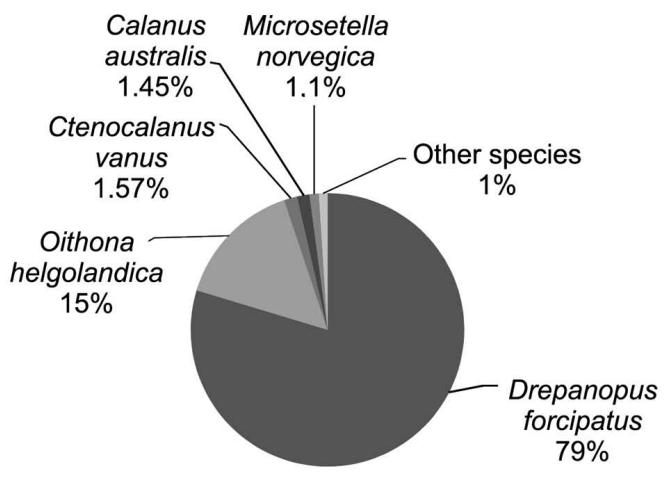

B

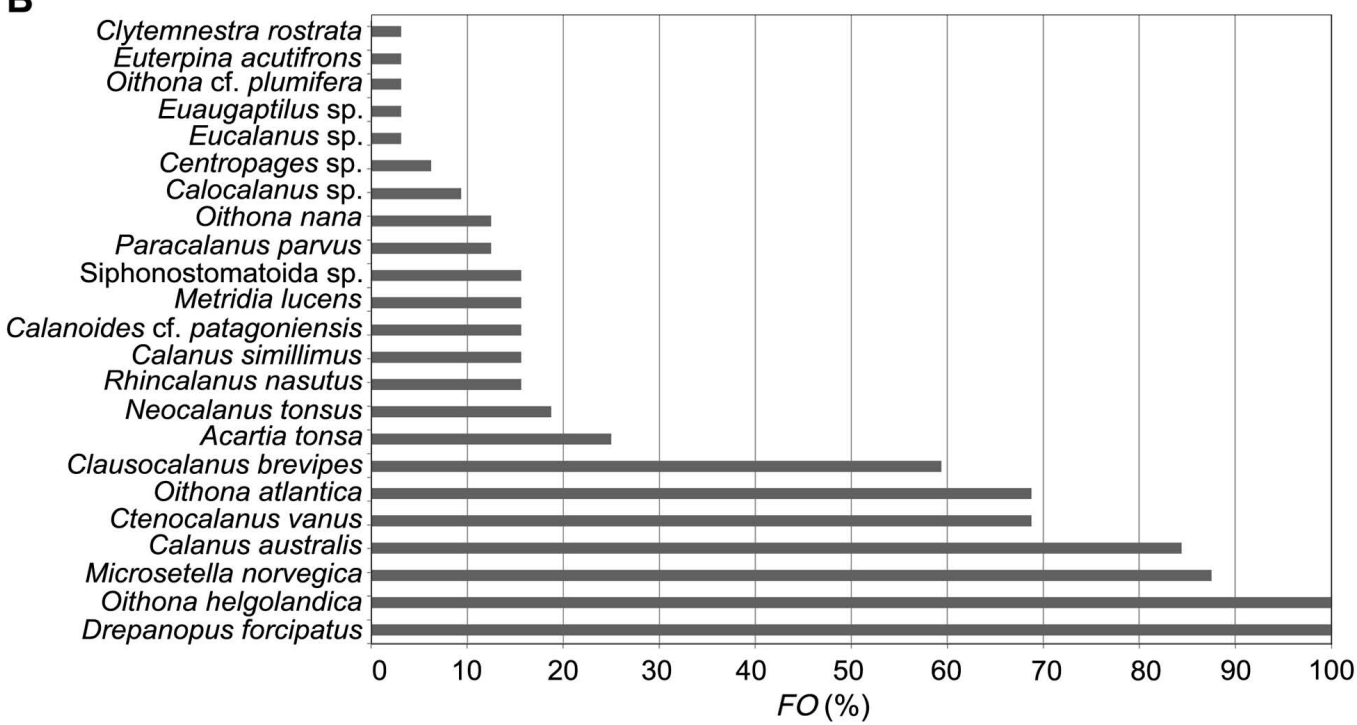

Fig. 2. - Relative abundance (A) and frequency of occurrence (B) of copepod taxa. In (A), Other species includes the rest of the copepod taxa with low relative abundance and frequency of occurrence listed in Table 1.

The distributions of all copepod taxa within the surveyed region are shown in Figure 3A-E. Among large calanids, $C$. australis dominated with abundances up to ca. 2000 ind $\mathrm{m}^{-3}$ at $49^{\circ} \mathrm{S}$ and ca. 700 ind $\mathrm{m}^{-3}$ at $51^{\circ} \mathrm{S}$. This species was distributed over the entire area, mainly in inner shelf waters, diminishing in the offshore direction. Other calanid species were present occasionally and in very low numbers: Calanus simillimus was recorded mostly at the outermost stations (max. 115 ind $\mathrm{m}^{-3}$ at $47^{\circ} \mathrm{S}$ ), N. tonsus (only C5) was found exclusively in the Grande Bay area at stations offshore (max. ca. 115-200 ind $\mathrm{m}^{-3}$ ), and $\mathrm{C} 4$ and $\mathrm{C} 5$ of Calanoides sp. (likely C. patagoniensis) were present at 51 and $53^{\circ} \mathrm{S}$ (max. 2 ind $\mathrm{m}^{-3}$ ) (Fig. 3A).

The medium-sized clausocalanid species were distributed over the entire shelf. They were represented by the dominant $D$. forcipatus, along with $C$. vanus and $C$. brevipes. Higher numbers of $D$. forcipatus were recorded over the inner shelf area of Grande Bay at $51^{\circ} \mathrm{S}$ (max. ca. 80000 ind $\mathrm{m}^{-3}$ ). Abundances of C. vanus were higher at two locations in mid-shelf waters (St. 273 at $47^{\circ} \mathrm{S}$ and St. 191 at $51^{\circ} \mathrm{S}, 2500-3500$ ind $\mathrm{m}^{-3}$ ). Much less abundant, $C$. brevipes was relatively better represented in stations at $47^{\circ} \mathrm{S}$, mostly in the offshore area (max. $c a .450$ ind $\mathrm{m}^{-3}$ ), decreasing gradually towards the south (Fig. 3B).
The smallest size range in the copepod community was represented by cyclopoid and harpacticoid species. The former group was dominated by $O$. helgolandica, distributed mainly in the northern area, with higher abundances over the inner shelf waters at $49^{\circ} \mathrm{S}$ (7000 and 11600 ind $\mathrm{m}^{-3}$ ). Other less abundant cyclopoids were Oithona nana, distributed in coastal and inner shelf waters at $51^{\circ} \mathrm{S}\left(\max .100 \mathrm{ind}^{-3}\right)$, and $O$. atlanti$c a$, present over the entire shelf with higher abundances offshore at 47 and $51^{\circ} \mathrm{S}$ (max. 200 ind $^{-3}$ ). Specimens of Oithona (possibly O. plumifera) were found in very low numbers (max. 3 ind $\mathrm{m}^{-3}$ ) offshore at $51^{\circ} \mathrm{S}$ (Fig. 3C). Among harpacticoids, M. norvegica dominated with 950 ind $\mathrm{m}^{-3}$ at $51^{\circ} \mathrm{S}$, increasing gradually in the offshore direction; Euterpina acutifrons (max. 5 ind $\mathrm{m}^{-3}$ ) and Clytemnestra rostrata (max. 0.3 ind $\mathrm{m}^{-3}$ ) were present occasionally in very low numbers (Fig. 3D).

Acartia tonsa (max. 1500 ind $\mathrm{m}^{-3}$ ) and Paracalanus parvus (max. ca. 500 ind $\mathrm{m}^{-3}$ ) were less abundant and less frequent species. Adult females and C5 of Metridia lucens, adult females of Calocalanus sp. and of R. nasutus, adult females and C5 of Centropages sp., C5 of Eucalanus sp., adult females of Euaugaptilus and one unidentified siphonostomatoid species were the least abundant copepod taxa $(<15$ ind $\mathrm{m}^{-3}$ ) (Fig. 3E). 


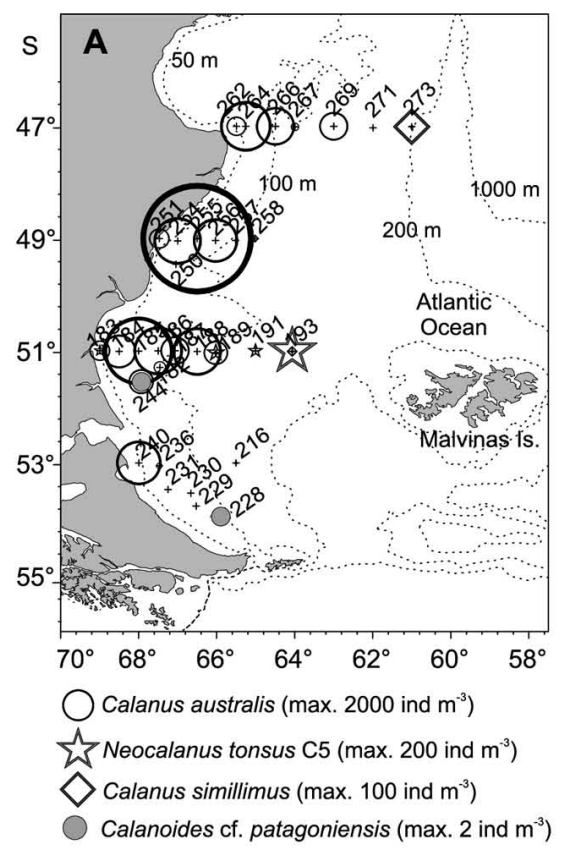

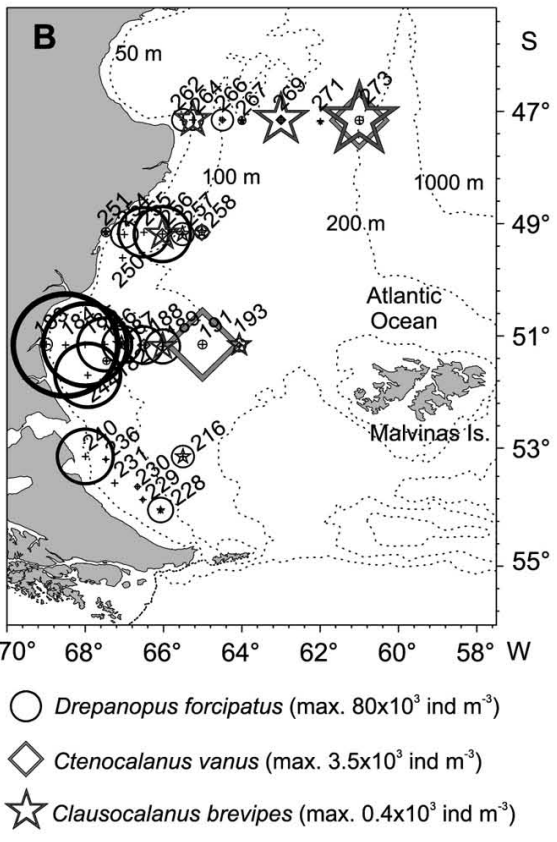

Clausocalanus brevipes (max. $0.4 \times 10^{3}$ ind $\mathrm{m}^{-3}$ )
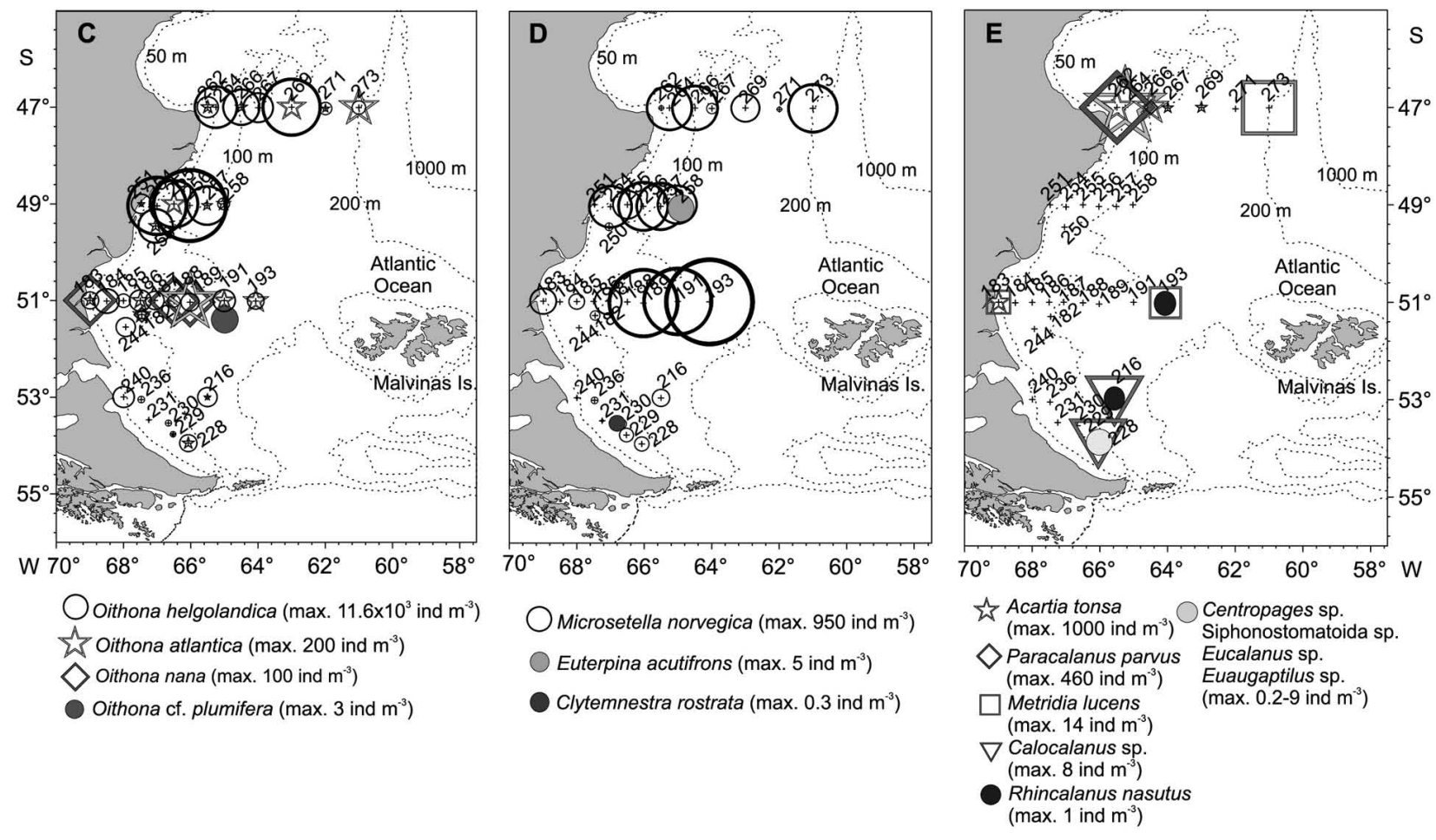

Fig. 3. - Spatial distribution and abundance of (A) large-sized calanid copepods (B) medium-sized clausocalanid copepods, (C) small-sized cyclopoid copepods, (D) small-sized harpacticoid copepods and (E) other less abundant and less frequent copepod taxa.

\section{Community structure}

Results from the one-way analysis of similarity performed on the station groups considered a priori as potentially different (ANOSIM, Table 2) indicated that there were no significant differences in the copepod assemblage among the four latitudinal sections (i.e. 47,49 , 51 and $53^{\circ} \mathrm{S}$ ) or across the shelf (i.e. inner shelf versus mid-shelf). The results showed a relatively homogeneous community throughout the study area. Low values of the statistic $R$ (in general $<0.25$ ) indicated small dif- ferences between groups, and that latitudinal section and bathymetric area per se were not significant factors in the ordination of stations. Negative values of the statistic $R$ showed that differences within groups were greater than those between groups (e.g. 47 versus $49^{\circ} \mathrm{S}$ ).

According to the SIMPER analysis, the typical species that contributed most to similarity in the area were $D$. forcipatus, $O$. helgolandica and $M$. norvegica. These species were the three most frequent and among the five most abundant taxa in the entire area. Although at lesser levels, C. australis (fourth in abundance and 
Table 2. - Analysis of similarity (ANOSIM test) performed to test for significant differences in the copepod community structure among latitudinal sections and shelf areas. For detailed derivation of groups see Materials and Methods. All values of $R$ in the pairwise tests are significant at $\mathrm{P}=0.05 \%$.

\begin{tabular}{lccc}
\hline Factors & Global $R$ & $\begin{array}{c}R \text { statistic } \\
\text { pairwise test }\end{array}$ & $\begin{array}{c}\text { Significance } \\
\text { level P (\%) }\end{array}$ \\
\hline Latitudinal sections & 0.185 & & 0.3 \\
$47-49^{\circ} \mathrm{S}$ & & -0.022 & 53.7 \\
$47-51^{\circ} \mathrm{S}$ & & 0.245 & 2.1 \\
$47-53^{\circ} \mathrm{S}$ & & 0.251 & 2.8 \\
$49-51^{\circ} \mathrm{S}$ & 0.084 & 16.9 \\
$49-53^{\circ} \mathrm{S}$ & 0.208 & 6.2 \\
$51-53^{\circ} \mathrm{S}$ & 0.299 & 1.0 \\
Across shelf areas & & & \\
Inner shelf-Mid-shelf & 0.051 & & 17.8 \\
\hline
\end{tabular}

Table 3. - SIMPER analysis. List of copepod species with major contributions to similarity over the southern Patagonian shelf. The percentage contributed by each species to similarity and the ratio between its average similarity value and the standard deviation of its contribution are indicated. Average between sample similarity in the entire area $\left(\overline{S_{i}}\right)$ was $59 \%$. Taxa were ranked in order of decreasing average contribution to similarity. Typical species are in bold (see Materials and Methods for details).

\begin{tabular}{lcr}
\hline \multicolumn{1}{c}{ Species } & $\begin{array}{c}\text { Contribution to } \\
\text { similarity }(\%)\end{array}$ & $\bar{S}_{i} / s d\left(S_{i}\right)$ \\
\hline Drepanopus forcipatus & $\mathbf{3 4 . 1 4}$ & $\mathbf{3 . 0 5}$ \\
Oithona helgolandica & $\mathbf{3 3 . 5 2}$ & $\mathbf{3 . 9 6}$ \\
Microsetella norvegica & $\mathbf{1 0 . 8 2}$ & $\mathbf{1 . 2 9}$ \\
Calanus australis & 8.76 & 0.78 \\
Oithona atlantica & 3.63 & 0.67 \\
\hline
\end{tabular}

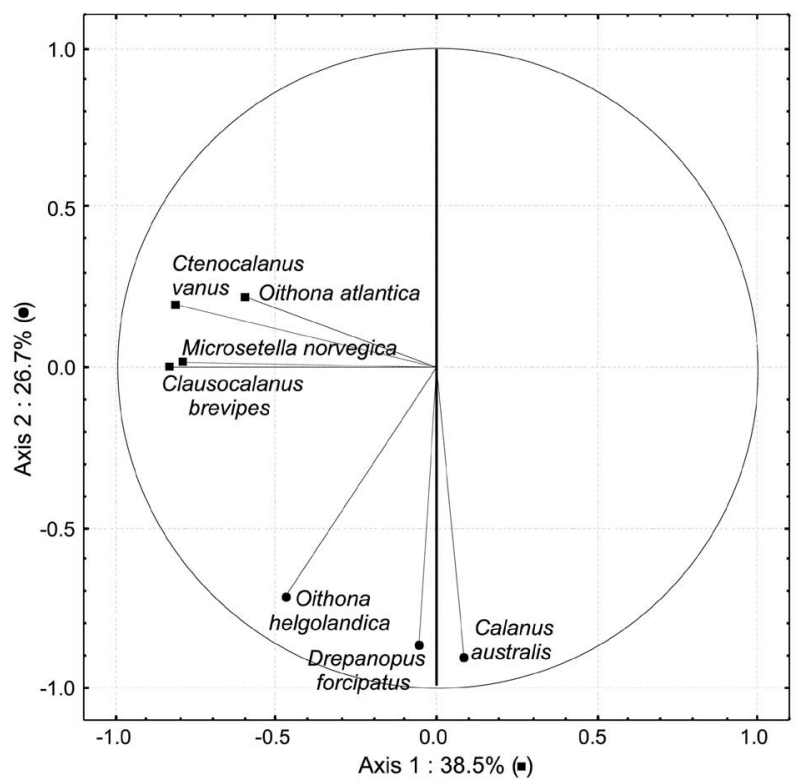

Fig. 4. - Principal component analysis (PCA) based on the correlation matrix. Representations on the ordination space of the correlations of species (variables) with the Axes 1 and 2 (circle of correlation).

occurrence) and $O$. atlantica (fifth in occurrence but low in abundance) also contributed significantly to similarity in the area (Table 3).

\section{Copepod assemblages}

According to the index of importance, $I$, only 7 copepod species (out of 23) were important and included
Table 4. - PCA ordination of dominant copepod species. Entries are eigenvalues of the correlation matrix between the ln-transformed abundance values of dominant copepod species and the PCA Axes 1 and 2. Species contributing most to axis placement and consequent ordination are in bold.

\begin{tabular}{lcc}
\hline Species/taxon & PCA Axis 1 & PCA Axis 2 \\
Eigenvalues & 3.0815 & 2.1362 \\
\% Total variance & 38.5 & 65.2 \\
\hline Drepanopus forcipatus & -0.0574 & $\mathbf{- 0 . 8 5 7 8}$ \\
Clausocalanus brevipes & $\mathbf{- 0 . 7 7 8 5}$ & 0.0148 \\
Ctenocalanus vanus & $\mathbf{- 0 . 8 0 9 0}$ & 0.1941 \\
Calanus australis & 0.0893 & $\mathbf{- 0 . 9 0 4 8}$ \\
Oithona helgolandica & -0.4665 & $\mathbf{- 0 . 7 0 3 8}$ \\
Oithona atlantica & $\mathbf{- 0 . 5 8 9 4}$ & 0.2202 \\
Microsetella norvegica & $\mathbf{- 0 . 8 2 4 9}$ & -0.0030 \\
\hline
\end{tabular}

in the PCA $\left(I_{i} \geq 20 \%\right.$, Table 1$)$. In decreasing order of importance, those species were $D$. forcipatus, $O$. helgolandica, $M$. norvegica, $C$. australis, C. vanus, $O$. atlantica and $C$. brevipes.

Results from the PCA indicated that all species included in the analysis were well represented by the two first axes, $\mathrm{C} 1$ and $\mathrm{C} 2$, which together explained $65.2 \%$ of the total variation in the distribution of copepod abundance. Axis 1 explained $38.5 \%$ of variance, and Axis 2 explained $26.7 \%$. The correlations of species (variables) with both axes are listed in Table 4, and their representations on the ordination space are shown in Figure 4. A clear and positive association of $D$. forcipatus, $C$. australis and $O$. helgolandica is evident from their joint and close relation to Axis 2. On the other hand, $C$. brevipes, $C$. vanus, $O$. atlantica and $M$. norvegica together as a separate assemblage correlated mostly with Axis 1 . As indicated by their orthogonal position, the two species assemblages are uncorrelated with each other.

\section{DISCUSSION}

The species composition and the relative abundances and distribution patterns of the copepod community were similar to those described from preceding studies. The copepod $D$. forcipatus was the most conspicuous component (because of its relative abundance and frequency of occurrence) of the mesozooplankton community, in keeping with previous surveys. Along with $C$. australis, this species has been repeatedly recognized as dominant in terms of biomass in the local mesozooplankton community (e.g. Sabatini et al. 2001, Sabatini 2008b). Furthermore, the distribution patterns of $D$. forcipatus and $C$. australis were mostly concentrated in the inner shelf waters of the Grande Bay area and northwards, coinciding with earlier studies in the region (e.g. Sabatini et al. 2000, Sabatini 2008b). Abundances of both species were significantly greater in the present study, especially in the case of $D$. forcipatus; this difference may be due to the use of a finemesh net $(66 \mu \mathrm{m}$ versus $\geq 150 \mu \mathrm{m})$. It is likely that the coarser nets used in previous studies undersampled the early copepodites (C1 in particular) of $D$. forcipatus (see Antacli et al. 2010).

The most notable differences in species composition and relative abundance between previous studies in the area and this study are twofold and most likely 
related to the use of a $66 \mu \mathrm{m}$ mesh net. First, the contribution of the smaller and less studied components to the mesozooplankton community was better established from our results. For example, Oithona helgolandica and $M$. norvegica were among those species, and their significant contributions to the community structure in terms of abundance and occurrence were, until now, completely unknown for the southern Patagonian shelf. Oithona helgolandica occupied the second place in the community after $D$. forcipatus in terms of abundance and occurrence; this species was distributed over the entire shelf and more abundantly to the north $\left(47-49^{\circ} \mathrm{S}\right)$. Microsetella norvegica showed a high frequency of occurrence over the entire shelf, had its highest abundances in mid-shelf waters at $51^{\circ} \mathrm{S}$ and in the northern area $\left(47-49^{\circ} \mathrm{S}\right)$, and was rather scarce in the coastal area of Grande Bay and at $53^{\circ} \mathrm{S}$. Second, the importance of $C$. australis in the community in comparison with previous studies was minor. Until this study, $C$. australis was considered the second species in relative abundance after $D$. forcipatus. Here, $C$. australis was the fourth most numerous species in the mesozooplankton community after $D$. forcipatus, $O$. helgolandica and C. vanus. Despite its comparatively low abundance (mean of 178 ind $\mathrm{m}^{-3}$, relative abundance $1.45 \%), C$. australis was among the four most frequent $(F O=84 \%)$ and important $(I=42.73 \%)$ species in the region, following $D$. forcipatus, $O$. helgolandica and $M$. norvegica. It is important to consider, nonetheless, that the slowly towed Bongo system that we used may have conversely resulted in underestimating the abundance of large-sized copepods. When the suitability of the system was evaluated, the fine $66-\mu \mathrm{m}$ net appeared to be more efficient than the coarser $150-\mu \mathrm{m}$ net in sampling small-sized taxa, without biasing the catchability of the older and larger copepodites of Calanus australis (Antacli et al., 2010). However, we cannot rule out completely the possibility that largesized copepods may have avoided the $20 \mathrm{~cm}$ opening of the small Bongo sampler because of a greater escape response (Anderson and Warren 1991). To be caught efficiently, some large-sized species may also require higher towing speeds than those recommended for vertical hauls such as those performed in this study.

Beyond our present findings highlighting the relative significance of small-sized species, it is worth noting that $D$. forcipatus stays as the most abundant key copepod over the southern Patagonian shelf, as is clearly shown in Figure 2. Current understanding of this species is not, however, in consonance with its presumed importance for the trophodynamics of the region, and its biology and ecology certainly deserve further research.

Strengthening the simple listing of counting results, the SIMPER analysis recognized $O$. helgolandica and $M$. norvegica, together with $D$. forcipatus, as typical species over the southern Patagonian shelf and, although to lesser extents, $C$. australis and $O$. atlantica contributed significantly to average similarity. Marine planktonic communities are often dominated by a few species, which develop key roles in energy transfer through their trophic web (Verity and Smetaceck
1996). This seems to be the case for the southern Patagonian shelf ecosystem, where a few copepod species dominated the mesozooplankton community in late summer 2004. Likely, O. helgolandica and M. norvegica play important roles in the regional trophic web. Oithona helgolandica may act as a key link between the microbial and the classical trophic webs (Turner 2004), similarly to closely related Oithona species occurring in other cold-temperate ecosystems (e.g. Gallienne and Robbins 2001, Narcy 2010). The pelagic harpacticoid $M$. norvegica, which often represents a large proportion of the total copepod abundance (e.g. Fish 1955, Yamazi 1956, Hirota 1964, Hirota and Hara 1975, Dugas and Koslow 1984, Uye et al. 2002) and mostly depends on food attached to surfaces (Koski et al. 2005), may play important roles as a secondary producer and in the degradation of aggregates, such as marine snow, during late summer in the region.

Despite its relatively low abundance $(R A=1.57 \%)$, $C$. vanus showed a relatively high frequency of occurrence $(F O=69 \%)$ and index of importance $(I=35.29)$. So, although not detected by the SIMPER as a typical species, its role in the ecosystem of the southern Patagonian shelf should be taken into account. This species could have a strong impact on phytoplankton biomass of the southern Patagonian shelf region, as has been suggested for sub-Antarctic and Antarctic ecosystems (e.g. Bernard and Froneman 2002, 2003, 2005).

The distribution patterns of the rest of the copepod taxa found in this study were broadly in agreement with previous records in the area (e.g. Ramírez 1970b, 1981, Ramírez and Sabatini 2000, Sabatini 2008a). Paracalanus parvus and $O$. nana were more abundant in inner waters, while $C$. brevipes, $C$. simillimus, $R$. nasutus, $M$. lucens, O. atlantica and C5s of $N$. tonsus were better represented in the offshore direction. Ctenocalanus vanus, recognized typically as a coastal species (Ramírez 1970b) was, however, mostly concentrated in offshore waters in this study. Although in very low abundance, the harpacticoid Clytemnestra rostrata was present in cold high-latitude waters at $53^{\circ} \mathrm{S}$, an unusual result because it is typically associated with warm subtropical waters (Ramírez 1970a). The concentration of $A$. tonsa over inner waters near to the coast at $47^{\circ} \mathrm{S}$ must be related to the presence of waters of low salinity coming mainly from the discharge of the Río Deseado. This is in agreement with the characteristic distribution reported for this species mainly in shallow coastal waters (Ramírez 1970a).

The homogeneity of the copepod community structure with both latitude and bathymetry over the southern Patagonian shelf in late summer 2004 was shown by the ANOSIM analysis. Similarly, Sabatini et al. (2012) found few differences in the copepod community structure in spring between the inner and mid-shelf sectors.

\section{Concluding remarks}

This is the first comprehensive study on the copepod community structure in the southern Patagonian shelf ecosystem based on sampling with a fine-mesh 
$(66 \mu \mathrm{m})$ net, as opposed to the standard coarser nets $(\geq 150 \mu \mathrm{m})$ utilized historically in the region to sample mesozooplankton.

Our results support the initial hypothesis that smallsized copepods are key components of the local mesozooplankton community over the southern Patagonian shelf in summer. From the deployment of a fine-mesh net, four major conclusions can be drawn from this study: (1) the microcopepods $O$. helgolandica and $M$. norvegica and the medium-sized $C$. vanus are significant components of the summer mesozooplankton community on the southern Patagonian shelf and they deserve special attention in future studies; (2) mediumsized $D$. forcipatus remains as the most important copepod in the region; (3) the relative importance of C. australis in the mesozooplankton community of the region may be less than previously recognized; and (4) the copepod community structure was nearly homogenous over the entire study area, both among latitudinal sections and across the shelf. All of these conclusions strongly support the importance of fine-mesh nets for collecting the smallest size fractions of the mesozooplankton in order to better assess the food web structure of the southern Patagonian shelf.

\section{ACKNOWLEDGEMENTS}

Special thanks are given to Dr. Fernando C. Ramírez for advising on zooplankton identification. We thank the crew and our colleagues on board RV Dr. E. L. Holmberg during cruise EH-03/04, and Guillermo Scampini in particular, for their help in sampling. G.S. passed away suddenly on February 9, 2005. Comments from anonymous reviewers improved the manuscript. This study was partially funded by fellowships from CONICET granted to J.A. and by CONICET PIP No. 5845 to M.S. This is contribution No.1847 of the Instituto Nacional de Investigación y Desarrollo Pesquero (INIDEP), Mar del Plata, Argentina.

\section{REFERENCES}

Alder V.A., Franzosi C.A. 2003. Distribución del picoplancton en el Mar Epicontinental Argentino. XIII Coloquio Argentino de Oceanografía, Mar del Plata.

Alder V.A., Franzosi C.A. 2005. Picoplankton abundances in two contrasting areas: the Southern Ocean and the Argentine Sea. IX SCAR Biology Symposium: Evolution and biodiversity in Antarctica, Curitiba.

Almandoz G.O., Ferrario M.E., Ferreyra G.A. Schloss I.R., Esteves J.L., Paparazzo F.E. 2007. The genus Pseudo-nitzschia (Bacillariophyceae) in continental shelf waters of Argentina (Southwestern Atlantic Ocean, $38^{\circ}-55^{\circ} \mathrm{S}$ ). Harmful Algae 6: 93-103. http://dx.doi.org/10.1016/j.hal.2006.07.003

Anderson J.T., Warren W.G. 1991. Comparison of catch rates among small and large Bongo samplers for Calanus finmarchicus copepodite stages. Can. J. Fish. Aquat. Sci. 48: 303-308. http://dx.doi.org/10.1139/f91-042

Antacli J.C. 2011. Estrategias de vida de los copépodos Drepanopus forcipatus y Calanus australis en relación con los recursos tróficos en la plataforma patagónica austral (Argentina, $47^{\circ}-55^{\circ} \mathrm{S}$ ). Tesis doctoral, Univ. Nac. Mar del Plata, 199 pp.

Antacli J.C., Sabatini M.E., Hernández D. 2010. Estimating copepods' abundance with paired nets: Implications of mesh size for population studies. J. Sea Res. 63: 71-77. http://dx.doi.org/10.1016/j.seares.2009.09.004

Bernard K.S., Froneman P.W. 2002. Mesozooplankton community structure in the Southern ocean upstream of the Prince Edward
Islands. Polar Biol. 25: 597-604.

Bernard K.S., Froneman P.W. 2003. Mesozooplankton community structure and grazing impact in the Polar Frontal Zone during austral autumn 2002. Polar Biol. 26: 268-275.

Bernard K.S., Froneman P.W. 2005. Trophodynamics of selected mesozooplankton in the west-Indian sector of the Polar Frontal Zone, Southern Ocean. Polar Biol. 28(8): 594-606. http://dx.doi.org/10.1007/s00300-005-0728-3

Björnberg T.K.S. 1981. Copepoda. In: Boltovskoy D. (ed.), Atlas del Zooplancton del Atlántico Sudoccidental y Métodos de Trabajo con el Zooplancton Marino. Public. Espec. INIDEP, Mar del Plata, pp. 587-679.

Borouche J.M., Saporta G. 1983. L'analyse des donnèes. Presses Universitaires de France, Paris, 126 pp.

Boxshall G.A., Halsey S.H. 2004. An introduction to copepod diversity. The Ray Society Series. Ray Society, London, 966 pp.

Bradford J.M., Ohman M.D., Jillet J.B. 1988. Larval morphology and development of Neocalanus tonsus, Calanoides macrocarinatus and Calanus australis (Copepoda: Calanoida) in the laboratory. N. Z. J. Mar. Freshw. Res. 22: 301-320. http://dx.doi.org/10.1080/00288330.1988.9516303

Bradford-Grieve J.M. 1999. Copepoda. In: Boltovskoy D. (ed.), South Atlantic Zooplankton. Backhuys Publishers, 2, Leiden, The Netherlands, pp. 869-1098.

Bulleri F., Chapman M.G., Underwood A.J. 2005. Intertidal assemblages on seawalls and vertical rocky shores in Sydney Harbour, Australia. Austral Ecol. 30: 655-667. http://dx.doi.org/10.1111/j.1442-9993.2005.01507.x

Cefarelli A.O., Ferrario M.E., Almandoz G.O., Atencio A.G., Akselman R., Vernet M. 2010. Diversity of the diatom genus Fragilariopsis in the Argentine Sea and Antarctic waters: morphology, distribution and abundance. Polar Biol. 33: 1463-1484. http://dx.doi.org/10.1007/s00300-010-0794-z

Clarke K.R., Gorley R.N. 2001. PRIMER v5: User Manual/Tutorial. Plymouth Routines in Multivariate Ecological Research. PRIMER-E: Plymouth, $91 \mathrm{pp}$.

Clarke K.R., Warwick R.M. 1994. Change in Marine Communities: An Approach to Statistical Analysis and Interpretation. Natural Environment Research Council, Plymouth Marine Laboratory, Plymouth, UK, 144 pp.

Di Mauro R., Capitanio F., Viñas M.D. 2009. Capture efficiency for small dominant mesozooplankters (Copepoda, Appendicularia) off Buenos Aires province $\left(34^{\circ} \mathrm{S}-41^{\circ} \mathrm{S}\right)$, Argentine sea, using two plankton mesh sizes. Braz. J. Oceanogr. 57(3): 205-214. http://dx.doi.org/10.1590/S1679-87592009000300004

Dugas J.D., Koslow J.A. 1984. Microsetella norvegica: a rare report of a potentially abundant copepod on the Scotian Shelf. Mar. Biol. 84: 131-134. http://dx.doi.org/10.1007/BF00392997

Evans M.S., Sell W.S. 1985. Mesh size and collection characteristics of 50-cm diameter conical plancton nets. Hydrobiologia 122: 97-104. http://dx.doi.org/10.1007/BF00032095

Fish C.J. 1955. Observations on the biology of Microsetella norvegica. Pap. Mar. Biol. Oceanogr. Deep Sea Res. 3(Suppl): 242-249.

Gallienne C.P., Robins D.B. 2001. Is Oithona the most important copepod in the world's oceans? J. Plankton Res. 23: 1421-1432. http://dx.doi.org/10.1093/plankt/23.12.1421

Grandori R. 1912. Studi sullo sviluppo larvale dei copepodi pelagici. Redia 8: 440-447.

Heron G.A., Bowman T.E. 1971. Postnaupliar developmental stages of the copepod crustaceans Clausocalanus laticeps, C. brevipes, and Ctenocalanus citer (Calanoida: Pseudocalanidae). In: Llano G.U., Wallen I.E. (eds), Biology of the Antartic seas, IV, Union Am. Geophys. 17: 141-165.

Hirota R. 1964. Zooplankton investigation in Hiunchi-nada in the Setonaikai (Inland Sea of Japan). I. The seasonal occurrence of copepods at three stations in Hiuchi-nada. J. Oceanogr. Soc. Japan 20: 24-31.

Hirota R., Hara M. 1975. Zooplankton investigations in YatsushiroKai, western Kyushu, Japan. Part I. Regional and seasonal occurrences of the important zooplankton. J. Oceanogr. Soc. Japan 31: 115-123. http://dx.doi.org/10.1007/BF02120194

Hopcroft R.R., Roff J.C., Lombard D. 1998. Production of tropical copepods in Kingston Harbour, Jamaica: the importance of small species. Mar. Biol. 130: 593-604. http://dx.doi.org/10.1007/s002270050281

Hulsemann K. 1991. The copepodid stages of Drepanopus forcipatus Giesbrecht, with notes on the genus and a comparison with other members of the family Clausocalanidae (Copepoda, Calanoida). Helgol. Meeresunters. 45: 199-224. 
http://dx.doi.org/10.1007/BF02365642

Hwang J., Kumar R., Dahms H., Tseng L., Chen Q. 2007. Mesh size affects abundance estimates of Oithona spp. (Copepoda, Cyclopoida). Crustaceana 80: 827-837. http://dx.doi.org/10.1163/156854007781363169

Koski M., Kiørboe T., Takahashi K. 2005. Benthic life in the pelagic: Aggregate encounter and degradation rates by pelagic harpacticoid copepods. Limnol. Oceanogr. 50(4): 1254-1263. http://dx.doi.org/10.4319/lo.2005.50.4.1254

Morales C.E., Torreblanca M.L, Hormazabal S., Correa-Ramírez M., Nuñez S., Hidalgo P. 2010. Mesoscale structure of copepod assemblages in the coastal transition zone and oceanic waters off central-southern Chile. Prog. Oceanogr. 84: 158-173. http://dx.doi.org/10.1016/j.pocean.2009.12.001

Narcy F. 2010. Life strategy of Oithona similis and role in trophic interactions in an arctic coastal ecosystem. Ph. D. thesis, Univ. Troms $\varnothing, 41 \mathrm{pp}$.

Olguín H., Alder V.A., Boltovskoy D. 2005. General trends of phytoplankton $(20-200 \mu \mathrm{m})$ from the Argentine Sea and Antarctic Ocean during austral summer 2002, with emphasis on diatom species. Ber. Polarforsch./Rep. Polar Res. 507: 167-168.

Paffenhöfer G.A. 1998. Heterotrophic protozoa and small metazoa: feeding rates and prey-consumer interactions. J. Plankton Res. 20: 121-134. http://dx.doi.org/10.1093/plankt/20.1.121

Pitois S.G., Shaw M., Fox C.J., Frid C.L.J. 2009. A new fine-mesh zooplankton time series from the Dove sampling station (North Sea). J. Plankton Res. 31: 337-343. http://dx.doi.org/10.1093/plankt/fbn121

Postel L., Fock H., Hagen W. 2000. Biomass and abundance. In: Harris R.P., Wiebe P.H., Lenz J., Skjoldal H.R., Huntley M. (eds), ICES Zooplankton Methodology Manual. Academic Press, San Diego, California, pp. 83-174. http://dx.doi.org/10.1016/B978-012327645-2/50005-0

Ramírez F.C. 1970a. Copépodos planctónicos del sector bonaerense del Atlántico Sudoccidental. Datos y resultados de las campañas pesquería. Serie Informes Técnicos, Mar del Plata, Publicación $\mathrm{N}^{\circ} 10 / \mathrm{XV}, 116 \mathrm{pp}$

Ramírez F.C. 1970b. Copépodos planctónicos del sector patagónico. Resultados de la Campaña 187 'Pesquería XI'. Physis 79: 473-476.

Ramírez F.C. 1971. Copépodos planctónicos de los sectores bonaerense y norpatagónico. Resultados de la Campaña 'Pesquería III'. Revista del Museo de La Plata n.s. Zoología 11: 73-94.

Ramírez F.C. 1981. Zooplancton y producción secundaria, Parte I, Distribución y variación estacional de los copépodos. In: Angelescu V. (ed.), Campañas de investigación pesquera realizadas en el Mar Argentino por los B/I 'Shinkai Maru' y 'Walther Herwig' y B/P 'Marburg', a-os 1978 y 1979, Resultados de la Parte Argentina. Contrib. Inst. Nac. Invest. Desarr. Pesq. 383: 202-212.

Ramírez F.C., Sabatini M.E. 2000. The occurrence of Calanidae species in waters off Argentina. Hydrobiologia 439: 21-42. http://dx.doi.org/10.1023/A:1004193401931

Sabatini M.E. 1990. The developmental stages (Copepodids I to VI) of Acartia tonsa Dana, 1849 (Copepoda, Calanoida). Crustaceana 59: 53-61. http://dx.doi.org/10.1163/156854090X00282

Sabatini M.E. 2008a. El ecosistema de la plataforma patagónica austral, Marzo-Abril 2000. Composición, abundancia y distribución del zooplancton. Rev. Invest. Desarr. Pesq. 9: 5-20.
Sabatini M.E. 2008b. Life history trends of copepods Drepanopus forcipatus (Clausocalanidae) and Calanus australis (Calanidae) in the southern Patagonian shelf (SW Atlantic). J. Plankton Res. 30: 981-996. http://dx.doi.org/10.1093/plankt/fbn062

Sabatini M.E., Ramírez F.C., Martos P. 2000. Distribution pattern and population structure of Calanus australis Brodsky, 1959 over the southern Patagonian Shelf off Argentina in summer. ICES J. Mar. Sci. 57: 1856-1866. http://dx.doi.org/10.1006/jmsc.2000.0969

Sabatini M.E., Álvarez Colombo G.L. 2001. Seasonal pattern of zooplankton biomass in the Argentinean shelf off Southern Patagonia $\left(45^{\circ}-55^{\circ} \mathrm{S}\right)$. Sci. Mar. 65: 21-31.

Sabatini M.E., Jiménez J., Rocco V. 2001. El zooplancton de las áreas de desove y cría de la población continental de sardina fueguina, Spratus fuegensis (Patagonia Austral, Argentina). Bol. Inst. Esp. Oceanogr. 17(3-4): 245-254.

Sabatini M.E., Reta R., Matano R. 2004. Circulation and zooplankton biomass distribution over the southern Patagonian shelf during late summer. Cont. Shelf. Res. 24: 1359-1373. http://dx.doi.org/10.1016/j.csr.2004.03.014

Sabatini M.E., Akselman R., Reta R., Negri R.M., Lutz V.A., Silva R.I., Segura V., Gil M.N., Santinelli N.H., Sastre A.V., Daponte C., Antacli J.C. 2012. Spring plankton communities in the southern Patagonian shelf: Hydrography, mesozooplankton patterns and trophic relationships. J. Mar. Syst. 94: 33-51. http://dx.doi.org/10.1016/j.jmarsys.2011.10.007

Santoferrara L.E., Alder V.A. 2009a. Abundance trends and ecology of planktonic ciliates of the south-western Atlantic (35$63^{\circ} \mathrm{S}$ ): a comparison between neritic and oceanic environments. J. Plankton Res. 31: 837-851. http://dx.doi.org/10.1093/plankt/fbp033

Santoferrara L.E., Alder V.A. 2009b. Morphological variability, spatial distribution and abundance of Helicostomella species (Ciliophora: Tintinnina) in relation to environmental factors (Argentine shelf; 40-55 ${ }^{\circ}$ S). Sci. Mar. 73: 701-716 http://dx.doi.org/10.3989/scimar.2009.73n4701

Turner J. 2004. The importance of small planktonic copepods and their roles in pelagic marine food webs. Zool. Stud. 43: 255-266.

Uye S., Aoto I., Onbé T. 2002. Seasonal population dynamics and production of Microsetella norvegica, a widely distributed but little-studied marine planktonic harpacticoid copepod. J. Plankton Res. 24(2): 143-153. http://dx.doi.org/10.1093/plankt/24.2.143

Vanucci M. 1968. Loss of organisms through the meshes. In: Tranter D.J. (ed.), Zooplankton sampling. Monogr. Oceanogr. Methodol. (Paris) 2: 77-86.

Verity P.G., Smetaceck V. 1996. Organism life cycles, predation, and the structure of marine pelagic ecosystems. Mar. Ecol. Prog. Ser. 130: 277-293. http://dx.doi.org/10.3354/meps 130277

Yamazi I. 1956. Plankton investigation in inlet waters along the coast of Japan. XIX. Regional characteristics and classification of inlet waters based on the plankton communities. Publ. Seto. Mar. Biol. Lab. 5: 24-64.

Zervoudaki S., Christou E.D., Nielsen T.G., Siokou-Frangou I., Assimakopoulou G., Giannakourou A., Maar A., Pagou K., Krasakopoulou E., Christaki U., Moraitou-Apostolopoulou M. 2007. The importance of small-sized copepods in a frontal area of the Aegean Sea. J. Plankton Res. 29: 317-338. http://dx.doi.org/10.1093/plankt/fbm018 